\title{
KAJIAN PEMUPUPUKAN P PADA LAHAN SAWAH BALAI BENIH INDUK UNTUK PERTUMBUHAN DAN PRODUKSI PADI (Oryza Sativa L.)
}

\author{
Riski Novarma, Nelvia, Herman \\ Pasca Fakultas Pertanian Universitas Riau \\ e-mail: cenelorita@yahoo.co.id
}

\begin{abstract}
ABSTRAK
Penelitian bertujuan untuk mendapatkan dosis pupuk P pada lahan sawah Balai Benih Induk (BBI) Pekanbaru Propinsi Riau untuk pertumbuhan dan hasil produksi padi yang optimal. Penelitian menggunakan Rancangan Acak Lengkap dengan 5 perlakuan yang terdiri dari 5 taraf (46; 57,5; 69; 80,5; $92 \mathrm{~kg} \mathrm{P2O5/ha),} \mathrm{masing-masing}$ perlakuan diulang 4 kali, dosis yang digunakan BBI adalah $69 \mathrm{~kg}$ P2O5/ha. Parameter yang diamati tinggi tanaman, jumlah anakan produktif, jumlah gabah per malai, bobot gabah bernas per sampel, bobot gabah bernas per meter persegi, bobot 1000 butir gabah dan indeks panen, serta $\mathrm{pH}, \mathrm{P}$ tersedia dan $\mathrm{P}$ potensial tanah. Data hasil pengamatan tiap parameter dianalisis secara statistik menggunakan analisis ragam dan uji lanjut dengan DNMRT taraf $5 \%$.

Hasil penelitian menunjukan bahwa penurunan dosis P dari $69 \mathrm{~kg}$ P2O5/ha (dosis BBI) $\mathrm{ke} 46 \mathrm{~kg}$ P2O5/ha menghasilkan tinggi tanaman, jumlah anakan produktif, jumlah gabah per malai, bobot gabah bernas per sampel, bobot gabah bernas per meter persegi dan indeks panen lebih tinggi dibadingkan pemberian P pada dosis BBI (69 kg P2O5/ha) dan di bawah maupun di atasnya (57,5, dan 80,5, $92 \mathrm{~kg}$ P2O5/ha). Pemberian dosis $57,5 \mathrm{~kg} \mathrm{P} 2 \mathrm{O} / \mathrm{ha}$ terhadap bobot 1000 butir gabah menghasilkan perbedaan yang nyata dari dosis $69 \mathrm{~kg}$ P2O5/ha (dosis BBI).
\end{abstract}

Kata Kunci $\quad$ : Pupuk P, Padi Lahan Sawah

\section{PENDAHULUAN}

Tanaman padi (Oryza sativa L.) merupakan tanaman pangan penghasil beras sebagai sumber energi yang umumnya dikonsumsi masyarakat Indonesia. Beras merupakan bahan makanan utama bagi sebagian besar penduduk Indonesia khususnya di Riau. Meningkatnya penduduk mengharuskan produksi padi terus meningkat. Salah satu usah dalam meningkatkan produksi padi adalah menjaga keseimbangan hara melalui pemupukan. Menurut Sutedjo (2002), pemupukan merupakan salah satu upaya yang dilakukan dalam rangka meningkatkan produksi pertanian disamping pemilihan bibit unggul bahkan sampai sekarang dianggap sebagai faktor dominan dalam produksi pertanian.

Optimalisasi produktivitas padi di lahan sawah merupakan salah satu peluang peningkatan produksi gabah nasional. Hal ini sangat dimungkinkan bila dikaitkan dengan hasil padi pada agroekosistem ini masih beragam antar lokasi dan belum optimal. Rata- rata produktivitas padi sawah 4,7 ton/ha sedangkan potensinya dapat mencapai 6-7 ton/ha. Belum optimalnya produktivitas padi di lahan sawah ini salah satunya disebabkan oleh rendahnya efisiensi pemupukan (Makarim et al., 2002).

Pemupukan $\mathrm{P}$ terus menerus pada tanah sawah intensifikasi menyebabkan kejenuhan $\mathrm{P}$ dan ketidakseimbangan hara di dalam tanah. Pemupukan $\mathrm{P}$ tidak lagi memberikan peningkatan hasil tanaman yang nyata. Efisiensi pemupukan menjadi rendah, dan kemungkinan unsur hara lain seperti $\mathrm{Zn}$ menjadi tidak tersedia (Subiksa et al., 2011). Belum optimalnya produktivitas padi di lahan sawah ini salah satunya disebabkan oleh rendahnya efisiensi pemupukan.

Berdasarkan permasalahan di atas, penulis telah melakukan penelitian dengan judul "Kajian Pemupukan P pada Lahan Sawah Balai Benih Induk untuk Pertumbuhan dan Produksi Padi (Oriza sativa L.)" guna mengetahui dosis pupuk $\mathrm{P}$ yang tepat untuk pertumbuhan dan produksi padi yang optimal. 
Penelitian ini bertujuan untuk mendapatkan dosis pupuk $\mathrm{P}$ yang tepat untuk pertumbuhan dan hasil produksi padi di lahan sawah Balai Benih Induk (BBI) Pekanbaru Propinsi Riau yang optimal.

\section{METODOLOGI PENELITIAN}

Penelitian dilaksanakan pada bulan Februari 2014 sampai bulan Juni 2014, di lahan sawah Balai Benih Induk (BBI) yang terletak di Marpoyan Kecamatan Bukit Raya, Kota Pekanbaru, Propinsi Riau.

\section{Bahan dan Alat}

Bahan yang digunakan dalam penelitian ini adalah benih padi varietas Ciherang, Pupuk Urea, TSP dan $\mathrm{KCl}$. Prepaton dan Decis untuk pencegahan terhadap hama dan penyakit.

Alat yang digunakan untuk analisis tanah di laboratorium antara lain : $\mathrm{pH}$ meter, peralatan distruksi : tabung digestion dan block digestion, alat distilasi, Flame photometer, Spectro photometer, gelas, timbangan analitik, penggaris.

\section{Perlakuan dan Rancangan Penelitian}

Penelitian dilakukan secara eksperimen menggunakan Rancangan Acak Lengkap (RAL), dengan 5 perlakuan dan 4 ulangan yaitu dua di bawah dan dua di atas dosis pupuk $\mathrm{P}$ yang digunakan. Adapun pupuk $\mathrm{P}$ yang dicobakan sebagai berikut:

$$
\begin{aligned}
& \mathrm{P}_{1} \quad: 46 \mathrm{~kg} \mathrm{P}_{2} \mathrm{O}_{5} / \mathrm{ha} \\
& \mathrm{P}_{2} \quad: 57,5 \mathrm{~kg} \mathrm{P}_{2} \mathrm{O}_{5} / \mathrm{ha}
\end{aligned}
$$

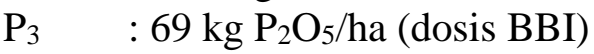

$$
\begin{aligned}
& \mathrm{P}_{4} \quad: 80,5 \mathrm{~kg} \mathrm{P}_{2} \mathrm{O}_{5} / \mathrm{ha}
\end{aligned}
$$

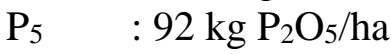

Model linier yang digunakan adalah : $\mathrm{Y}_{\mathrm{ij}}=\mu+\mathrm{Gi}+\varepsilon \mathrm{ij}$

\section{Keterangan :}

$\begin{array}{ll}\text { Yij }= & \text { nilai pengamatan dari } \\ \text { perlakuan ke-i } & \text { ulangan ke-j } \\ \mu= & \text { nilai rata-rata umum } \\ \mathrm{Gi}= & \text { pengaruh dari pupuk P ke-i } \\ \varepsilon \mathrm{ij}= & \text { pengaruh galat dari pupuk } \mathrm{P}\end{array}$
ke-i ulangan ke-j

\section{Pelaksanaan Penelitian}

\section{Persemaian}

Benih padi terlebih dahulu direndam selama 24 jam dengan air bersih, benih dipilih yang tenggelam di dalam tempat perendaman. Benih ditiriskan lalu diperam selama 48 jam, setelah pemeraman keluarlah akar-akar yang berukuran kecil dengan warna putih itu ciri-ciri benih sudah siap disebar di tempat persemaian yang telah dipersiapkan.

\section{Persiapan Lahan}

Lahan diolah dengan mencangkul tanah dan membuang gulma dengan memotong, memecah dan membalik tanah sampai tanah gembur kemudian lahan diratakan. Setelah lahan bersih lalu dilakukan pembuatan plot sebanyak 20 unit, ukuran setiap plot yakni $2 \mathrm{~m}^{2}$ dan setiap plot diberi label perlakuan dan ulangan.

\section{Penanaman}

Bibit padi dipindahkan dari persemaian ke plot percobaan yang telah persiapkan pada umur 21 HST, Jarak tanam $20 \times 25 \mathrm{~cm}$, setiap plot percobaan terdapat 28 rumpun tanaman. Satu lubang tanam terdapat dua tanaman.

\section{Pemberian Perlakuan}

Perlakuan yang digunakan yaitu pupuk $\mathrm{P}$. Dosis pupuk $\mathrm{P}$ sesuai dengan dosis perlakuan yaitu : $\mathrm{P} 1=46 \mathrm{~kg} \mathrm{P}_{2} \mathrm{O}_{5} / \mathrm{ha}$ $\left(9,29 \mathrm{~g} / 2 \mathrm{~m}^{2}\right), \mathrm{P} 2=57,5 \mathrm{~kg} \mathrm{P}_{2} \mathrm{O}_{5} / \mathrm{ha}(11,5$

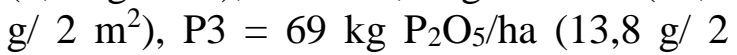

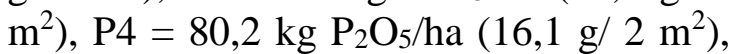

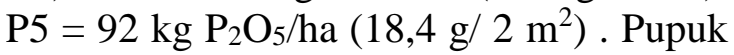
$\mathrm{P}$ diberian 1 minggu setelah tanam.

\section{Pemupukan}

Pemberian pupuk urea dan $\mathrm{KCl}$ tetap menggunakan takaran dosis BBI yaitu urea $20 \mathrm{~g} / \mathrm{m}^{2}$ dan $\mathrm{KCl} 30 \mathrm{~g} / \mathrm{m}^{2}$. Pemberian pupuk dilakukan secara sebar merata di dalam plot dengan berhati-hati supaya jangan sampai terkena tanaman karena 
akan menyebabkan tanaman layu bahkan mati.

\section{Penyulaman dan Penyiangan}

Penyulaman dilakukan 1 minggu setelah tanam pada tanaman yang tidak tumbuh. Penyiangan dilakukan secara manual yaitu dengan mencabut setiap gulma yang tumbuh kemudian gulma yang sudah dicabut dibenamkan ke dalam lumpur pada lahan sawah sedalam $10 \mathrm{~cm}$ dalam setiap plot percobaan.

\section{Pengendalian hama dan penyakit}

Pengendalian hama burung dilakukan dengan cara pemasangan jaring disekeliling plot percobaan hingga menutupi seluruh tanaman padi, gunanya sebagai perangkap kawanan atau kelompok burung mulai dari burung yang kecil hingga burung yang besar.

Pengendalian penyakit yakni menggunakan insektisida berupa prevhaton dan decis pemberian dilakukan secara semprot, dilakukan satu kali selama penelitian dengan dosis yang diberikan 0,8 $\mathrm{ml} / 1$ liter air. Penyemprotan dilakukan dengan didapati daun terinfeksi berubah hijau keabu-abuan, menggulung dan mati.

\section{Pemanenan}

Panen dilakukan pada saat tanaman padi sudah berumur 130 hari dicirikan dengan $90 \%$ tanaman sudah menguning. Pemanenan menggunakan alat berupa sabit dengan cara memanen tanaman padi dilakukan pemotongan pangkal batang tanaman padi.

\section{Pengamatan}

\section{Analisis Tanah dan Pengamatan}

\section{Pengamatan di Laboratorium}

Analisis sifat kimia tanah sebelum penanaman meliputi : Analisis tanah meliputi: $\mathrm{pH} \mathrm{H}_{2} \mathrm{O}, \mathrm{KCl}, \mathrm{C}$-Organik, $\mathrm{N}$ total, $\mathrm{P}$ tersedia, $\mathrm{P}$ potensial dan $\mathrm{K}$ Potensial, KTK, KB, kation dapat tukar
(K, Na, Ca, Mg-dd) dan kemasaman dapat tukar (Al-dd dan H-dd).

\section{Pengamatan di Lapangan}

Tinggi tanaman, Jumlah anakan produktif, Jumlah gabah permalai, Bobot Gabah Bernas per Sampel, Bobot Gabah Bernas per Meter Persegi $\left(\mathrm{m}^{2}\right)$, Bobot 1000 butir gabah (gram).

\section{HASIL DAN PEMBAHASAN}

\subsection{Sifat Kimia Tanah Sawah Sebelum Penanaman}

Sifat kimia tanah sawah Balai Benih Induk (BBI) yang digunakan dalam penelitian disajikan pada Tabel 1

Tabel 1. Sifat kimia tanah sawah sebelum penanaman

\begin{tabular}{|c|c|c|}
\hline Sifat Kimia & Nilai & Kriteria*) \\
\hline $\mathrm{pH} \mathrm{H}_{2} \mathrm{O}(1: 2,5)$ & 5,7 & Agak Masam \\
\hline $\operatorname{KCl}(1: 2,5)$ & 5,2 & Masam \\
\hline C-Organik (\%) & 3.9 & Tinggi \\
\hline N Total $(\%)$ & 1,75 & Sangat Tinggi \\
\hline $\mathrm{C} / \mathrm{N}$ & 2,2 & Sangat rendah \\
\hline P-tersedia $(\mathrm{mg} / \mathrm{kg})$ & 156 & Sangat tinggi \\
\hline P-potensial (mg/kg) & 198 & Sangat tinggi \\
\hline K-potensial $(\mathrm{mg} / \mathrm{kg})$ & 27,9 & Sedang \\
\hline $\begin{array}{l}\text { Kation basah dapat } \\
\text { ditukar }\left(\mathrm{c} \mathrm{mol}\left({ }^{+}\right) / \mathrm{kg}\right) \text { : } \\
\mathrm{K} \text {-dd }\end{array}$ & 0,17 & Rendah \\
\hline Ca-dd & 6,27 & Sedang \\
\hline Mg-dd & 0,19 & Sangat rendah \\
\hline Na-dd & 0,59 & Sedang \\
\hline KB & 40,11 & Sedang \\
\hline $\begin{array}{l}\mathrm{KTK}(\mathrm{me} / 100 \mathrm{~g})(\mathrm{c} \\
\left.\mathrm{mol}\left({ }^{+}\right) / \mathrm{kg}\right)\end{array}$ & 18 & Sedang \\
\hline $\mathrm{H}-\mathrm{dd}\left(\mathrm{c} \mathrm{mol}\left(^{+}\right) / \mathrm{kg}\right)$ & 0,23 & Sangat rendah \\
\hline Al-dd $\left(\mathrm{c} \mathrm{mol}\left(^{+}\right) / \mathrm{kg}\right)$ & 0,01 & Sangat rendah \\
\hline Kejenuhan Al & 0,13 & Sangat rendah \\
\hline
\end{tabular}

Ket: *)Kriteria (Lembaga Penelitian Tanah, 1983) 
Tabel 1 menunjukkan bahwa tanah sawah yang digunakan dalam penelitian bereaksi agak masam, C-Organik yang tinggi dan $\mathrm{N}$ Total yang sangat tinggi menyebabkan $\mathrm{C} / \mathrm{N}$ sangat rendah. Dilihat dari $\mathrm{P}$ tersedia tergolong sangat tinggi dan $\mathrm{P}$ potensial juga tergolong sangat tinggi. Kadar $\mathrm{P}$ tanah yang berada di BBI umumnya berada di atas $100 \mathrm{mg} / \mathrm{kg}$ tanah sehingga jauh lebih tinggi dari batas bawah untuk status P. Hal ini disebabkan terdapatnya senyawa kompleks yang sukar larut, terbentuknya senyawa kompleks ini akan menyebabkan fiksasi $\mathrm{P}$ menurun sehingga meningkatkan P-tersedia (Whitelaw, 2000). Kation yang dapat dipertukarkan Ca-dd, Na-dd, KB yang tergolong sedang dan $\mathrm{Mg}$ yang sangat rendah meskipun $\mathrm{K}$ dd nilainya rendah.

Hanafiah (2005) menyatakan bahwa $\mathrm{Mg}$ tergolong sangat rendah disebabkan terjadinya pencucian selama pelapukan, karena terbentuk pada daerah suhu dan curah hujan yang rendah. Pupuk anorganik $(\mathrm{KCl})$ yang diberikan akan cepat larut, sehingga kehilangan unsur $\mathrm{K}$ pun juga cepat, karena $\mathrm{K}$ sangat mobil. Selain diserap tanaman, $\mathrm{K}$ dapat hilang karena difiksasi mineral liat dan mengalami pelindian/pencucian sehingga dengan hanya memberikan pupuk anorganik tidak mempengaruhi ketersediaan $\mathrm{K}$ dalam tanah terutama setelah penanaman.

\subsection{Tinggi Tanaman}

Hasil sidik ragam (enunjukkan bahwa pemberian pupuk $\mathrm{P}$ berpengaruh tidak nyata terhadap tinggi tanaman padi sawah. Tinggi tanaman setelah dilakukan uji lanjut DNMRT taraf 5\% disajikan pada Tabel 2.
Tabel 2. Tinggi tanaman $(\mathrm{cm})$ padi sawah varietas Ciherang yang diberi beberapa dosis pupuk $\mathrm{P}$

\begin{tabular}{|c|c|}
\hline $\begin{array}{c}\text { Pupuk P }(\mathrm{kg} \\
\left.\mathrm{P}_{2} \mathrm{O}_{5} / \mathrm{ha}\right)\end{array}$ & Tinggi Tanaman $(\mathrm{cm})$ \\
\hline 46 & 100,25 \\
57,5 & 99,45 \\
69 & 99,47 \\
80,5 & 98,92 \\
92 & 98,26 \\
\hline
\end{tabular}

Tabel 2 memperlihatkan rata-rata tinggi tanaman yang tertinggi pada dosis $46 \mathrm{~kg}$ $\mathrm{P}_{2} \mathrm{O}_{5} /$ ha walaupun pemberian pupuk $\mathrm{P}$ berbeda tidak nyata terhadap tinggi tanaman padi (Tabel 2). Hal ini disebabkan oleh ketersediaan $\mathrm{P}$ tanah sudah sangat tinggi sehingga pemberian $\mathrm{P}$ tidak direspon oleh tanaman padi. Kapasitas penyerapan unsur hara sudah mencapai batas optimum sehingga apabila dilakukan penambahan dosis pupuk $\mathrm{P}$ maka akan berbeda tidak nyata terhadap tinggi tanaman padi diduga jumlah pupuk yang diberikan sudah mencukupi untuk pertumbuhan tanaman, bahkan pemberian pupuk $\mathrm{P}$ yang terlalu tinggi dapat menekan pertumbuhan tanaman. Dosis pupuk $\mathrm{P}$ optimum padi sawah di lahan BBI terdapat pada dosis yang lebih rendah dibandingkan pemberian dosis umum yang berlaku di BBI selama ini (69 $\left.\mathrm{kg} \mathrm{P}_{2} \mathrm{O}_{5} / \mathrm{ha}\right)$. Selain tinggi tanaman hasil yang optimum dari dosis (46 kg $\mathrm{P}_{2} \mathrm{O}_{5} / \mathrm{ha}$ ) juga ditunjukkan pada percobaan jumlah anakan produktif, jumlah gabah per malai, bobot gabah bernas per sampel dan indeks panen. Tinggi tanaman padi yang terendah terdapat pada pemberian dosis $\mathrm{P} 92 \mathrm{~kg}$ $\mathrm{P}_{2} \mathrm{O}_{5} /$ ha. Tinggi tanaman padi pada pemberian berbagai dosis pupuk $\mathrm{P}$ terlihat lebih rendah dibandingkan deskripsi padi Ciherang. 
Sarief (1986) kelebihan dalam aplikasi pupuk akan berakibat pada pertumbuhan tanaman, bahkan unsur hara yang dikandung oleh pupuk tidak dapat dimanfaatkan oleh tanaman. Apabila kadar $P$ berlebihan, maka serapan unsur mikro di dalam tanah akan terganggu sehingga akan menghambat pertumbuhan tinggi tanaman.

\subsection{Jumlah Anakan Produktif}

Hasil sidik ragam (Lampiran 4) menunjukkan bahwa pemberian pupuk $\mathrm{P}$ berpengaruh tidak nyata terhadap jumlah anakan produktif padi sawah. Jumlah anakan produktif padi sawah umur 48 HST hasil uji lanjut DNMRT taraf 5\% disajikan pada Tabel 3.

Tabel 3. Jumlah anakan produktif (rumpun) padi sawah varietas Ciherang yang diberi beberapa dosis pupuk $\mathrm{P}$

\begin{tabular}{|c|c|}
\hline $\begin{array}{c}\text { Pupuk P (kg } \\
\left.\mathrm{P}_{2} \mathrm{O}_{5} / \mathrm{ha}\right)\end{array}$ & $\begin{array}{c}\text { Jumlah Anakan } \\
\text { Produktif (rumpun) }\end{array}$ \\
\hline 46 & 17,19 \\
57,5 & 15,88 \\
69 & 16,40 \\
80,5 & 16,39 \\
92 & 16,34 \\
\hline
\end{tabular}

Tabel 3 memperlihatkan pemberian pupuk

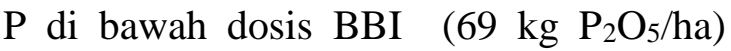
maupun di atasnya berbeda tidak nyata terhadap jumlah anakan produktif padi sawah, namun jumlah anakan produktif yang tertinggi pada pemberian pupuk $\mathrm{P}$ dosis $46 \quad \mathrm{~kg} \quad \mathrm{P}_{2} \mathrm{O}_{5} / \mathrm{ha}$. Sedangkan pemberian dengan dosis $92 \mathrm{~kg} \mathrm{P}_{2} \mathrm{O}_{5} / \mathrm{ha}$ menunjukkan penurunan jumlah anakan produktif. Hal ini disebabkan unsur $\mathrm{P}$ yang terdapat di tanah sawah sudah sangat tinggi sehingga penamabahan $\mathrm{P}$ tidak berpengaruh terhadap peningkatan jumlah anakan produktif. Anakan produktif terbanyak ditunjang pula oleh keberadaan unsur hara, pemberian pupuk yang sesuai dengan dosis dan kebutuhan dapat meningkatkan hasil, sebaliknya pemberian yang berlebihan akan menurunkan hasil tanaman.

Terdapatnya unsur $\mathrm{P}$ tersedia maupun $\mathrm{P}$ potensial sudah sangat tinggi (Tabel 1), kelebihan jumlah $\mathrm{P}$ yang tersedia ataupun diberikan akan mengakibatkan ketidakseimbangan hara bahkan menggangu ataupun menghambat hara lain karena hara $\mathrm{P}$ akan bersifat antagonis.

\subsection{Jumlah Gabah per Malai}

Hasil sidik ragam (Lampiran 4) menunjukkan bahwa pemberian pupuk $\mathrm{P}$ berpengaruh tidak nyata terhadap jumlah gabah per malai padi sawah. Jumlah gabah per malai dengan hasil uji lanjut DNMRT taraf 5\% disajikan pada Tabel 4.

Tabel 4. Jumlah gabah per malai padi sawah varietas Ciherang yang diberi beberapa dosis pupuk $\mathrm{P}$

\begin{tabular}{|c|c|}
\hline $\begin{array}{c}\text { Pupuk P (kg } \\
\left.\mathrm{P}_{2} \mathrm{O}_{5} / \mathrm{ha}\right)\end{array}$ & $\begin{array}{c}\text { Jumlah Gabah per Malai } \\
\text { (butir) }\end{array}$ \\
\hline 46 & 140,32 \\
57,5 & 137,52 \\
69 & 138,02 \\
80,5 & 136,99 \\
92 & 138,83 \\
\hline
\end{tabular}

Tabel 4 memperlihatkan pemberian pupuk $\mathrm{P}$ di bawah dosis BBI (69 $\mathrm{kg} \mathrm{P}_{2} \mathrm{O}_{5} / \mathrm{ha}$ ) maupun di atasnya berbeda tidak nyata terhadap jumlah gabah per malai. Namun terdapat peningkatan pada dosis yang diturunkan menjadi $46 \mathrm{~kg} \mathrm{P}_{2} \mathrm{O}_{5} / \mathrm{ha}$ yaitu setengah dari dosis BBI. Hal ini disebabkan tanah sawah BBI sudah mempunyai kandungan $\mathrm{P}$ tersedia dan $\mathrm{P}$ potensial yang sangat tinggi, sedangkan unsur hara lain terutama $\mathrm{Mg}$ tergolong rendah sehingga menjadi penghambat bagi tanaman padi meskipun hara lain $\mathrm{Ca}, \mathrm{Na}$ dan $\mathrm{K}$ tergolong sedang dan tinggi. Jumlah 
$\mathrm{P}$ yang tersedia berlebihan juga ikut mengganggu hara dalam bentuk anion yang lain terutama $\mathrm{SO}_{4}, \mathrm{Cl}$, Mo sehingga mengahambat terhadap pertumbuhan dan metabolisme tanaman.

Unsur $\mathrm{P}$ di dalam sel-sel tanaman berfungsi sebagai komponen beberapa enzim dan protein, ATP dalam metabolisme tanaman seperti proses fotosintesis dan respirasi tanaman, sebagai pembentuk biji dan buah. Selain itu ketersediaan $\mathrm{P}$ yang cukup pada periode awal pertumbuhan akan berpengaruh terhadap fase primordia dan pembentukan bagian reproduktif tanaman.

Peningkatan jumlah gabah per malai dapat dipengaruhi oleh tinggi tanaman kemampuan tanaman mengekspresikan panjang malai sangat dipengaruhi oleh periode inisiasi malai yang termasuk dalam periode kritis tanaman, Jumlah gabah per malai ditentukan pada fase reproduksi. Hal ini diduga peningkatan tinggi tanaman dapat mempengaruhi peningkatan panjang daun sehingga luas daun juga meningkat. Luas daun yang meningkat dapat mempengaruhi peningkatan proses fotosintesis sehingga fotosintat yang dihasilkan dapat meningkat. Fotosintat dapat ditranslokasikan ke malai sehingga mempengaruhi peningkatan jumlah gabah per malai.

Jumlah gabah per malai dipengaruhi oleh tinggi tanaman dan jumlah anakan produktif. Peningkatan tinggi tanaman dan jumlah anakan produktif dapat meningkatkan jumlah gabah per malai. Semakin tinggi tanaman dan banyak jumlah anakan produktif maka jumlah gabah per malaipun meningkat. Hasil korelasi dari jumlah gabah per malai dengan tinggi tanaman dan jumlah anakan produktif masing-masing adalah $r=0.808$ dan $r=0.584$ dimana korelasi keeratan kuat dan keeratan sangat kuat

\subsection{Bobot Gabah Bernas per Sampel}

Hasil sidik ragam (Lampiran 5) menunjukkan bahwa pemberian pupuk $\mathrm{P}$ berpengaruh tidak nyata terhadap bobot gabah bernas per sampel padi sawah. Bobot gabah per sampel dengan hasil uji lanjut DNMRT taraf 5\% disajikan pada Tabel 5.

Tabel 5. Bobot gabah bernas per sampel (gram) padi sawah varietas Ciherang yang diberi beberapa dosis pupuk $\mathrm{P}$

\begin{tabular}{|c|c|}
\hline $\begin{array}{c}\text { Pupuk P (kg } \\
\left.\mathrm{P}_{2} \mathrm{O}_{5} / \mathrm{ha}\right)\end{array}$ & $\begin{array}{c}\text { Bobot Gabah Bernas per } \\
\text { Sampel (gram) }\end{array}$ \\
\hline 46 & 16,52 \\
57,5 & 14,42 \\
69 & 11,90 \\
80,5 & 15,06 \\
92 & 13,37 \\
\hline
\end{tabular}

Tabel 5 memperlihatkan dosis $\mathrm{P} 46 \mathrm{~kg}$ $\mathrm{P}_{2} \mathrm{O}_{5} /$ ha dan peningkatan $\mathrm{P}$ hingga $92 \mathrm{~kg}$ $\mathrm{P}_{2} \mathrm{O}_{5} /$ ha dari dosis yang digunakan $\mathrm{BBI}$ (69 $\mathrm{kg} \quad \mathrm{P}_{2} \mathrm{O}_{5} / \mathrm{ha}$ ) berbeda tidak nyata terhadap bobot gabah bernas per sampel. Namun ada kecenderungan peningkatan bobot gabah bernas per sampel apabila dosis $\mathrm{P}$ diturunkan ke $46 \mathrm{~kg} \quad \mathrm{P}_{2} \mathrm{O}_{5} / \mathrm{ha}$. Bobot gabah bernas per sampel yang terendah pada pemberian dengan dosis $\mathrm{P}$ BBI (69 kg $\mathrm{P}_{2} \mathrm{O}_{5} / \mathrm{ha}$ ). Dosis pupuk $\mathrm{P}$ yang terendah bisa meberikan hasil yang lebih baik dari dosis anjuran BBI.

Jumlah anakan yang banyak diharapkan dapat menghasilkan malai yang banyak pula, namun jika jumlah anakan terlalu banyak dan batang terlalu tinggi menyebabkan tanaman mudah rebah. Selain itu anakan yang terlalu banyak tanpa asupan hara yang optimal akan menyebabkan banyak bulir hampa sehingga produksi menjadi rendah. Khush et al. (1998) menyatakan bahwa anakan yang cukup dan semuanya produktif 
bertujuan untuk efisiensi fotosintat yang dihasilkan. Jumlah bulir per satuan luas dapat ditingkatkan dengan cara menaikkan jumlah bulir per malai sehingga hal tersebut dapat mengkompensasikan pengurangan anakan.

Unsur $\mathrm{P}$ di dalam sel-sel tanaman berfungsi sebagai komponen beberapa enzim dan protein, ATP dalam metabolisme tanaman seperti proses fotosintesis dan respirasi tanaman sebagai pembentuk biji dan buah. Selain itu ketersediaan $\mathrm{P}$ yang cukup pada periode awal pertumbuhan akan berpengaruh terhadap fase primordia dan pembentukan bagian reproduktif tanaman. Pembentukan pati dan biji fosfor (P) yang memegang peranan. Fosfor berpengaruh mempercepat pematangan dan pembentukan biji. Fosfor juga dapat memperbesar nisbah biji sebagian fosfor terdapat dalam buah dan biji, Pemberian dosis $\mathrm{P}$ yang terlalu tinggi menyebabkan ketidakseimbangan hara sehingga berpengaruh terhadap bobot gabah bernas yang dihasilkan.

\subsection{Bobot Gabah Bernas per Meter Persegi}

Hasil sidik ragam (Lampiran 4) menunjukkan bahwa pemberian pupuk $\mathrm{P}$ berpengaruh tidak nyata terhadap bobot gabah bernas per meter persegi $\left(\mathrm{m}^{2}\right)$ padi sawah. Bobot gabah per meter persegi dengan hasil uji lanjut DNMRT taraf 5\% disajikan pada Tabel 6 .
Tabel 6. Bobot gabah bernas per meter persegi $\left(\mathrm{gram} / \mathrm{m}^{2}\right)$ padi sawah varietas Ciherang yang diberi beberapa dosis pupuk $\mathrm{P}$

\begin{tabular}{|c|c|}
\hline $\begin{array}{c}\text { Pupuk P }(\mathrm{kg} \\
\left.\mathrm{P}_{2} \mathrm{O}_{5} / \mathrm{ha}\right)\end{array}$ & $\begin{array}{c}\text { Bobot Gabah Bernas } \\
\text { per Meter Persegi } \\
\left(\mathrm{gram} / \mathrm{m}^{2}\right)\end{array}$ \\
\hline 46 & 469,00 \\
57,5 & 429,50 \\
69 & 433,60 \\
80,5 & 497,40 \\
92 & 411,80 \\
\hline
\end{tabular}

Tabel 6 memperlihatkan pemberian pupuk

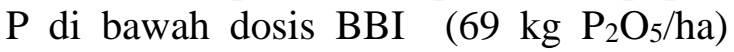
maupun di atasnya tidak berbeda nyata terhadap bobot gabah bernas per meter persegi. Dari data bobot gabah bernas per meter persegi rata-rata produksi setiap perlakuan adalah $46 \mathrm{~kg} \mathrm{P}_{2} \mathrm{O}_{5} / \mathrm{ha}(469,00$ g), 57,5 kg $\mathrm{P}_{2} \mathrm{O}_{5} / \mathrm{ha}(429,50 \mathrm{~g}), 69 \mathrm{~kg}$ $\mathrm{P}_{2} \mathrm{O}_{5} / \mathrm{ha} \quad(433,60 \mathrm{~g}), \quad 80,5 \quad \mathrm{~kg} \quad \mathrm{P}_{2} \mathrm{O}_{5} / \mathrm{ha}$ $(497,40 \mathrm{~g}) 92 \mathrm{~kg} \mathrm{P}_{2} \mathrm{O}_{5} / \mathrm{ha}(411,80 \mathrm{~g})$ jika dibandingkan dengan deskripsi rata-rata produksi/ha lebih rendah dibandingkan rata-rata produksi Ciherang yaitu $6 \mathrm{t} / \mathrm{ha}$. Produksi pada perlakuan $46 \mathrm{~kg} \mathrm{P}_{2} \mathrm{O}_{5} / \mathrm{ha}$ lebih rendah $(21,83 \%), 57,5 \mathrm{~kg} \mathrm{P}_{2} \mathrm{O}_{5} / \mathrm{ha}$ $(28,5 \%), 69 \mathrm{~kg} \mathrm{P}_{2} \mathrm{O}_{5} / \mathrm{ha}(27,83 \%), 80,5$ $\mathrm{kg} \mathrm{P}_{2} \mathrm{O}_{5} / \mathrm{ha}(17,16 \%), 92 \mathrm{~kg} \mathrm{P}_{2} \mathrm{O}_{5} / \mathrm{ha}$ $(31,5 \%)$ dibandingkan rata-rata produksi dari deskripsi Ciherang. Rendahnya produksi ini sudah diawali dari pertumbuhan vegetatif yang tertekan sejak awal, hal ini berkaitan erat dengan keterkaitan hara yang tidak seimbang akibat pemberian pupuk $\mathrm{P}$ yang terus menerus.

Fosfor merupakan komponen struktural dari sejumlah senyawa penting, molekul pentransfer energi ADP dan ATP (adenosine di- dan trifosfat), NAD, NADPH dan senyawa system informasi genetic DNA dan RNA (asam desoksiribo dan ribonukleat). 


\subsection{Bobot 1000 Butir Gabah}

Hasil sidik ragam (Lampiran 4) menunjukkan bahwa pemberian pupuk $\mathrm{P}$ berbeda nyata terhadap bobot 1000 gabah padi sawah. Bobot 1000 butir gabah dengan hasil uji lanjut DNMRT taraf 5\% disajikan pada Tabel 7.

Tabel 7. Bobot 1000 butir gabah (gram) padi sawah varietas Ciherang yang diberi beberapa dosis pupuk $\mathrm{P}$

\begin{tabular}{|c|c|}
\hline $\begin{array}{c}\text { Pupuk P }(\mathrm{kg} \\
\left.\mathrm{P}_{2} \mathrm{O}_{5} / \mathrm{ha}\right)\end{array}$ & $\begin{array}{c}\text { Bobot } 1000 \text { Butir } \\
\text { Gabah }(\text { gram })\end{array}$ \\
\hline 46 & $21,81 \mathrm{~b}$ \\
57,5 & $28,10 \mathrm{a}$ \\
69 & $17,69 \mathrm{~b}$ \\
80,5 & $17,81 \mathrm{~b}$ \\
92 & $18,37 \mathrm{~b}$ \\
\hline
\end{tabular}

Angka-angka yang diikuti oleh huruf kecil yang sama, tidak berbeda nyata menurut uji DNMRT pada taraf 5\%

Tabel 7 memperlihatkan pemberian pupuk $\mathrm{P}$ dosis $57,5 \mathrm{~kg}_{2} \mathrm{O}_{5} / \mathrm{ha}$ ), di bawah dosis BBI (69 $\mathrm{kg} \mathrm{P}_{2} \mathrm{O}_{5} / \mathrm{ha}$ ), berbeda nyata terhadap bobot 1000 butir gabah padi sawah. Pemberian pupuk $P$ yang berimbang dapat meningkatkan hasil tanaman, hal ini diduga suplai $\mathrm{P}$ selain diambil dari pupuk $\mathrm{P}$ yang diberikan juga berasal dari $\mathrm{P}$ tersedia tanah dimana dari analisis awal $\mathrm{P}$ tersedia tergolong sangat tinggi yaitu $156(\mathrm{mg} / \mathrm{kg})$ sehingga dapat dilihat bobot 1000 butir gabah sudah mendapatkan hasil yang tertinggi dengan dosis yang lebih rendah dari dosis BBI. Dosis pupuk $\mathrm{P} 57,5 \mathrm{~kg} \mathrm{P}_{2} \mathrm{O}_{5} / \mathrm{ha}$ ) dari hasil yang diperoleh sudah sesuai dengan deskripsi padi Ciherang. Bobot 1000 butir gabah yang terendah diperoleh dari dosis pupuk $\mathrm{P}$ anjuran $\mathrm{BBI}$ yaitu $69 \mathrm{~kg} \mathrm{P}_{2} \mathrm{O}_{5} / \mathrm{ha}$. Bobot 1000 butir gabah menyatakan banyaknya biomassa yang terkandung dalam gabah. Semakin bernas gabah menandakan biomassa yang terkandung di dalamnya semakin banyak. Kebernasan gabah sangat ditentukan oleh terjaminnya ketersediaan hara dan terjaminnya proses fisiologi tanaman. Semakin banyak gabah yang terbentuk semakin tinggi beban tanaman untuk membentuk gabah yang berisi (bernas). Karakteristik tanaman untuk menghasilkan gabah bernas selain dipengaruhi oleh faktor genetik juga dipengaruhi oleh ketersediaan hara dan terjaminnya proses fisiologis tanaman.

\section{Kesimpulan dan Saran Kesimpulan}

Berdasarkan hasil penelitian, maka dapat disimpulkan sebagai berikut :

1. Penurunan dosis pupuk $\mathrm{P}$ ke $46 \mathrm{~kg}$ $\mathrm{P}_{2} \mathrm{O}_{5} /$ ha dari $69 \mathrm{~kg} \mathrm{P}_{2} \mathrm{O}_{5} / \mathrm{ha}$ (dosis $\mathrm{BBI}$ ) menghasilkan tinggi tanaman, jumlah anakan produktif, jumlah gabah per malai, bobot gabah bernas per sampel, bobot gabah bernas per meter persegi dan indeks panen yang tidak berbeda nyata.

2. Pemberian dosis pupuk $\mathrm{P} 46 \mathrm{~kg} \mathrm{P}_{2} \mathrm{O}_{5} / \mathrm{ha}$ yang diturunkan dari dosis BBI $(69 \mathrm{~kg}$ $\mathrm{P}_{2} \mathrm{O}_{5} / \mathrm{ha}$ ) didapatkan perbedaan yang nyata pada bobot 1000 butir gabah.

\section{Saran}

Perlu dilakukan penelitian-penelitian lebih lanjut dalam pemberian dosis pupuk $\mathrm{P}$, dengan memberikan dosis yang lebih rendah dari dosis penelitian ini untuk mendapatkan pertumbuhan dan produksi padi sawah (Oriza sativa L.) yang optimal.

\section{DAFTAR PUSTAKA}

Hanafiah. K. A. 2005. Dasar-dasar Ilmu Tanah. Raja Grafindo Persada. Jakarta.

Khush, G.S., R.C. Aquino, S.S. Virmani, \& T.S. Bharaj. 1998. Use of Tropical Japonica Germplasm for Enhancing Heterosis in Rice. In: Virmani S.S., E.A. Siddiq, K. Muralidharan (eds). 
Advance in Hybrid Rice Technology. Proceedings of the 3rd International Symposium on Hybrid Rice. Hyderabad, 14-16 Nov 1996. IRRI. Manila.

Makarim. A. K. 2002. Pemupukan Berimbang Pada Tanaman Pangan: Khususnya Padi Sawah. Seminar Rutin Puslitbang Tanaman Pangan. Bogor.

Sarief. E.S. 1986. Kesuburan dan Pemupukan Tanah Pertanian. Pustaka Buana. Bandung.
Subiksa, Ladiyani R.W., dan Diah Setyorini. 2011. Perangkat uji tanah sawah. IGM. Balai Penelitian Tanah. Bogor.

Sutedjo. 2002. Pupuk dan Cara Pemupukan. Rineka Cipta. Jakarta.

Whitelaw. 2000. Growth promotion of plants inoculated with phosphate solubilizing fungi. Adv. Agron. 69 : 99-151. 